\title{
EFFECT OF RICE STRAW COMPOST ENRICHED WITH POTASSIUM RICH MATERIALS ON DRY MATTER AND WATER CONSUMPTION OF BARLEY UNDER DROUGHT CONDITIONS
}

\author{
Manal Mubarak $^{1}$ and K. F. T. Elbagoury ${ }^{2}$
}

\begin{abstract}
The main objective of this research was to study the effect of rice straw compost as a source of potassium on the barley dry matter under drought conditions using three ratios of the value of water consumption (100\%, $80 \%$ and 60\%). A pot experiment was conducted using loamy and sandy soils in the greenhouse of Soil Sci. Dept., Fac. of Agric., Ain Shams University. The suggested treatments can be summarized as control (without compost addition), (rice straw compost), (1\% rice straw $+1 \%$ banana compost), ( $1 \%$ rice straw $+1 \%$ vegetables compost) and $(1 \%$ rice straw + potassium dissolving bacteria $(P D B))$. The obtained results show the value of time growth for barley under control,1\% rice straw compost (RSC), 1\% RSC+ $1 \%$ banana residues compost (BRC), $(1 \% R S C+1 \%$ vegetables residues compost (VRC) and $1 \%$ RSC+ potassium dissolving bacteria (PDB), respectively. The maximum potassium availability of the loamy soil were 2.96, 3.58, 3.38, 3.2 and $3.35 \mathrm{meq} / \mathrm{l}$ at 475, 494, 508, 457 and 350 hour, respectively. The corresponding figures for the sandy soil were 475, 375, 550, 575 and 425 hour producing the maximum potassium of 0.41, 0.58, 1.71, 1.08 and 1.06 meq/l at different time growth under rice straw compost treatments. The effect both water consumption and its potassium content on barley dry matter was significant and clear effect noticeable by using the treatment of rice straw compost (RSC)+bananas residues compost (BRC) on water consumption under 100 and $60 \%$.
\end{abstract}

Key words: Drought stress, Water consumption, Potassium rich materials and Organic wastes

1. Soil Dept., Fac .of Agric., Ain Shams Univ., Shoubra El-Kheima, Cairo.

2. Agric. Eng. Dept., Fac. of Agric., Ain Shams Univ., Shoubra El-Kheima, Cairo. 


\section{INTRODUCTION}

The supplies of water and nitrogen to a plant during its critical
growth stages are the main factors that define crop yield. A crop
experiences irregular water deficits during its life cycle in rain fed agriculture. An effective anti-stress-oriented approach therefore ought to focus on increasing the units of water productivity. Yield increases resulting from $\mathrm{K}$ application mostly appeared under conditions of mild water deficit. As described for sugar beet, finding the critical period of crop $\mathrm{K}$ sensitivity is a decisive step in understanding its impact on water-use efficiency. It has been shown that an insufficient supply of $\mathrm{K}$ during crucial stages in the yield formation of cereals (wheat, spring triticale), maize, and sugar beet coincides with a depressed development in the yield components. The application of $\mathrm{K}$ fertilizer to plants is a simple agronomic practice used to increase crop tolerance to a temporary water shortage. It may be that the improvement of a plant's access to K during mild water-deficiency stress will increase water uptake by the root cells, which in turn increases their osmotic potential and thereby allows extension growth. This growth in turn promotes access to other mineral elements (including nitrogen) and water, which favor plant growth and yield (Grzebisz et al., 2013). In modern agriculture, the economically and environmentally sound practice of production requires some insight into processes that increase productivity per water unit. The depletion of soil nutrient reserves is a logical consequence of soil mining-oriented agriculture, which results in soil-fertility decline. Wood $\boldsymbol{e t}$ al. (2000) and Grzebisz and Diatta (2012) reported that the main reason for low yields is not only the water supply but also the limited supply of nutrients, mainly potassium. The majority of arable lands worldwide are cropped with cereals (FAO STAT, 2012). Plants treated with two regimes of irrigation water, $100 \%$ of evapotranspiration $\left(\mathrm{ET}_{\mathrm{c}}\right)$ (control) and $60 \%$ of $\mathrm{ET}_{\mathrm{c}}$ and three levels of (PDB) solution (0.0 (control), 20 and $40 \mathrm{mg} \mathrm{l}^{-1}$ ). In comparison to water-stressed plants without PBZ treatment, waterstressed plants treated with PBZ (40 $\mathrm{mg} \mathrm{l}^{-1}$ ) had significant higher grain yield and WUE (Mostafa et al, 2012).

The highly potassium content in such wastes, besides the limitation of $\mathrm{K}$ resources and the higher price of potash on the local and international 
markets has reduced the demand of potassium, as most farmers are unwilling to put more potash into the soil.

The objective of this study was to maximize the utilization of the composted rice straw alone or mixed with potassium rich materials (banana or vegetables residues composts) as well as biofertilizer to reduce water consumption values and increase barley dry matter yield under drought conditions.

\section{MATERIALS AND METHODS}

A pot experiment was conducted in the greenhouse of Soil Sci. Dept., Fac. of Agric., Ain Shams University using two types of soil, loamy from Shalaqan farm and sandy soil from Khatatba. Rice straw, Banana and vegetables residues were composted by adding $5 \mathrm{~kg}$ potassium sulphate / $100 \mathrm{~kg}$ of such residues. The suggested treatments could be summarized as following:

1. Control (containing on $90 \mathrm{mg} \mathrm{K} 2 \mathrm{O}$ /pot with $\mathrm{N}$ and $\mathrm{P}$ fertilizers being added at the recommended rates),

2. $1 \%$ rice straw compost (RSC),

3. $1 \% \mathrm{RSC}+1 \%$ banana residues compost (BRC),

4. $1 \% \mathrm{RSC}+1 \%$ vegetable residues compost (VRC)

5. 1\% RSC+bio-fertilizer (potassium dissolving bacteria, PDB) added at the rate of $20 \mathrm{ml} /$ pot containing $4 \mathrm{~kg}$ soil. Each $1 \mathrm{ml}$ of the used bio-fertilizer was containing $10^{8}$ bacterium cells.

Physical and chemical analysis of the used soil and compost materials were determined according to Jackson (1973) while the available and total macronutrients were determined according to Page $\boldsymbol{e t}$ al. (1982).

After good homogeneity of soil, compost and bio fertilizer, 15 barley grains (Hordeum vulgare, variety Giza 123) were cultivated, and thinned to 10 seedlings after complete germination, in pots containing $4 \mathrm{~kg}$ soil samples and taken into account under greenhouse conditions. The values of crop coefficient (Doorenbos et al., 1977 and Allen et al., 1998) presented in Table 1. 
Table 1: Values for crop coefficient (Doorenbos et al., 1977 and Allen $e t$ al., 1998) for barley crop at different stages of growth

\begin{tabular}{clccc}
\hline Stage & \multicolumn{1}{c}{ Growth stage } & Month & $\begin{array}{c}\text { Crop } \\
\text { coefficient }\end{array}$ & $\begin{array}{c}\text { Length } \\
\text { (days) }\end{array}$ \\
\hline 1 & Establishment (initial) & November & 0.3 & 15 \\
2 & Vegetative (development) & December & 0.7 & 15 \\
\hline
\end{tabular}

\section{Soil and climate:}

Soil and compost properties in the pots under study are given in Table 2 (a, b, c and d).

Table 2a: Some initial physical properties of the studied soils

\begin{tabular}{ccccccccc}
\hline \multicolumn{2}{c}{ Particle size distribution $(\%)$} & FC & WP & Bd & WHC & Texture \\
$(\%)$ & $(\%)$ & $\left(\mathrm{g} / \mathrm{cm}^{3}\right)$ & $\begin{array}{c}(\mathrm{mm} / \mathrm{m}) \\
\text { C. sand }\end{array}$ & F. sand & Silt & Clay & $(\%)$ \\
\hline 4.58 & 27.39 & 40.73 & 27.28 & 24.8 & 8.4 & 1.32 & 21.6 & loam \\
50.00 & 43.5 & 5.0 & 1.5 & 12.2 & 5.5 & 1.60 & 10.7 & Sandy \\
\hline
\end{tabular}

$\mathrm{FC}=$ field capacity; $\mathrm{WP}=$ welting point, $\mathrm{FC}$ and $\mathrm{WP}$ were determined as percentage in weight; $\mathrm{Bd}=$ bulk density; $\mathrm{WHC}=$ water holding capacity

Table 2b: Effect of applied treatments on some physical properties

\begin{tabular}{|c|c|c|c|c|c|}
\hline Soil & Treatments & $\begin{array}{l}\text { FC } \\
(\%)\end{array}$ & $\begin{array}{l}\text { WP } \\
(\%)\end{array}$ & $\begin{array}{c}\text { Bd } \\
\left(\mathrm{g} / \mathrm{cm}^{3}\right)\end{array}$ & $\begin{array}{c}\text { WHC } \\
(\mathbf{m m} / \mathbf{m})\end{array}$ \\
\hline \multirow{4}{*}{ 胥 } & $1 \%$ RSC & 19.4 & 9.3 & 1.3 & 13.1 \\
\hline & $1 \% \mathrm{RSC}+1 \% \mathrm{BRC}$ & 58.3 & 27.9 & 1.3 & 39.5 \\
\hline & $1 \% \mathrm{RSC}+1 \% \mathrm{VRC}$ & 22.5 & 7.5 & 1.3 & 19.5 \\
\hline & $1 \%$ RSC+ Bio. & 35.2 & 11.7 & 1.3 & 30.6 \\
\hline \multirow{4}{*}{ 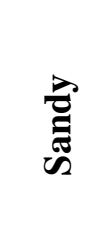 } & $1 \%$ RSC & 31.4 & 17.2 & 1.6 & 22.7 \\
\hline & $1 \% \mathrm{RSC}+1 \% \mathrm{BRC}$ & 39 & 11.8 & 1.6 & 43.5 \\
\hline & $1 \% \mathrm{RSC}+1 \% \mathrm{VRC}$ & 52.2 & 21.1 & 1.6 & 49.8 \\
\hline & $1 \%$ RSC+ Bio. & 54 & 15.1 & 1.6 & 62.2 \\
\hline
\end{tabular}

Table 2c: Initial chemical properties in soil paste extract of the studied soils

\begin{tabular}{|c|c|c|c|c|c|c|c|c|c|c|}
\hline \multirow[t]{2}{*}{ Soil } & \multirow{2}{*}{$\begin{array}{c}\text { ECe } \\
(\mathrm{dS} / \mathrm{m})\end{array}$} & \multirow[t]{2}{*}{ pH } & \multicolumn{8}{|c|}{ Soluble ions in saturated soil extract (meq/l) } \\
\hline & & & $\mathbf{K}^{+}$ & $\mathbf{N a}^{+}$ & $\mathbf{C a}^{+2}$ & $\mathbf{M g}^{+2}$ & $\mathrm{Cl}^{-}$ & $\mathrm{HCO}_{3}^{-}$ & $\mathrm{CO}_{3}=$ & $\mathrm{SO}_{4}=$ \\
\hline Loamy & 1.17 & 7.34 & 0.78 & 2.94 & 4.00 & 4.00 & 5.10 & 3.30 & 0.00 & 3.32 \\
\hline Sandy & 0.51 & 7.5 & 0.50 & 0.88 & 2.40 & 1.33 & 1.03 & 2.90 & 0.00 & 1.18 \\
\hline
\end{tabular}


Table 2d: Chemical analysis of the used composts

\begin{tabular}{c|c|c|c|c|c|c|c|c|c|c}
\hline Compost & $\begin{array}{c}\text { pH } \\
\mathbf{1 : 1 0}\end{array}$ & $\begin{array}{c}\mathbf{E C} \\
\text { d Susp.) }\end{array}$ & $\begin{array}{c}\mathbf{1 : 1 0} \\
\text { extract }\end{array}$ & $\mathbf{O M}$ & $\mathbf{C} / \mathbf{N}$ & $\mathbf{r a t i o}$ & \multicolumn{3}{|c|}{ Total nutrients, } & \multicolumn{3}{|c}{$\begin{array}{c}\text { Available } \\
\text { nutrients } \\
\text { ppm }\end{array}$} \\
\hline RSC & 7.61 & 1.88 & 55.0 & 24.5 & 1.30 & 0.21 & 2.31 & 289 & 173 & 466 \\
\hline BRC & 7.50 & 1.69 & 54.0 & 18.5 & 1.64 & 0.30 & 3.85 & 323 & 211 & 589 \\
\hline VRC & 7.33 & 1.74 & 41.7 & 16.3 & 2.69 & 0.36 & 1.25 & 432 & 246 & 490 \\
\hline
\end{tabular}

Data from the agricultural climatologic profiles (2013) is shown in Table 3.

Table 3: Climatologic data during months of evaluation (Agricultural climatologic profiles, 2013 and http://www.wunderground.com).

\begin{tabular}{llllll}
\hline Month & $\mathbf{T}_{\max }\left({ }^{\mathbf{0}} \mathbf{c}\right)$ & $\mathbf{T}_{\min }\left({ }^{\mathbf{0}} \mathbf{c}\right)$ & $\mathbf{R H}_{\text {mean }}(\boldsymbol{\%})$ & $\mathbf{U}(\mathbf{k m} / \mathbf{h})$ & $\mathbf{n}$ (hour) \\
\hline November & 25.5 & 17 & $* 59.0$ & 10.4 & 8.4 \\
December & 18.9 & 10.8 & $* 56.0$ & 10.2 & 7.1 \\
\hline
\end{tabular}

$\left(\mathrm{T}_{\max }\right)=$ maximum temperature; $\left(\mathrm{T}_{\min }\right)=$ minimum temperature; $*\left(\mathrm{RH}_{\text {mean }}\right)=$ calculate $\left(\mathrm{RH}_{\text {min }}+\mathrm{RH}_{\text {min }}\right) / 2 ;\left(\mathrm{RH}_{\text {mean }}\right)=$ given mean relative humidity; $\left(\mathrm{RH}_{\text {max }}\right)=$ maximum relative humidity; $\left(\mathrm{RH}_{\min }\right)=$ minimum relative humidity; $(\mathrm{U})=$ wind speed and $(\mathrm{n})=$ daily sunshine.

Equations used to estimate K-availability and irrigation management parameters:

a. Representative soil samples were taken out at 7, 15 and 30 days from the experiment start. Each treatment was replicated 6 times; two out of them were taken to represent a plant and soil samples at 3 and 6 weeks, respectively, after cultivation. In each plant samples, shoots and roots were separated, dried at $65-70{ }^{\circ} \mathrm{C}$ then their dry weights were recorded and $\mathrm{K}$ content was determined in wet digests as described by Page et al., 1982. Each soil sample was subjected to the determination of several parameters expressing $\mathrm{K}$ availability, where ( $\mathrm{NH}_{4} \mathrm{OAC}-\mathrm{K}$ ) was determined according to Jackson (1973). The obtained data were statistically subjected to analysis of variance, regression and correlation analysis according to the procedures outlined by Snedecor and Cochran (1982).

Estimating reference evapotranspiration: Evapotranspiration from meteorological data was estimated using the following equation (Allen et al., 1998) comprising a number of climatological and physical variables: 


$$
E T_{o}=\frac{0.408 \Delta\left(R_{n}-G\right)+\gamma \frac{900}{T+273} u_{2}\left(e_{s-} e_{a}\right)}{\Delta+\gamma\left(1+0.34 u_{2}\right)}
$$

where:

$\mathrm{ET}_{\mathrm{o}}=$ reference evapotranspiration (mm/day);

$\Delta=$ slope of vapor pressure curve at air temperature $\left(\mathrm{kPa}^{\mathrm{o}} \mathrm{c}^{-1}\right)$;

$\mathrm{R}_{\mathrm{n}}=$ net radiation at the crop surface $\left(\mathrm{M} \mathrm{J} \mathrm{m}^{-2} \mathrm{day}^{-1}\right)$;

$\mathrm{G}=$ soil heat flux density, $\left(\mathrm{M} \mathrm{J} \mathrm{m}^{-2} \mathrm{day}^{-1}\right)$;

$\gamma=$ psychrometric constant $\left(\mathrm{kPa}^{\circ} \mathrm{c}^{-1}\right)$;

$\mathrm{T}=$ air temperature at $2 \mathrm{~m}$ height $\left({ }^{\circ} \mathrm{C}\right)$;

$\mathrm{u}=$ wind speed at $2 \mathrm{~m}$ above ground surface $\left(\mathrm{m} \mathrm{s}^{-1}\right)$;

$\mathrm{e}_{\mathrm{a}}=$ actual vapor pressure $(\mathrm{kPa})$; and

$\mathrm{e}_{\mathrm{s}}=$ saturation vapor pressure $(\mathrm{kPa})$.

Estimating crop evapotranspiration. The following equation was used (Doorenbos et al., 1977).

$$
E T_{c}=E T_{o} \times K_{c}
$$

where:

$\mathrm{ET}_{\mathrm{c}}=$ crop evapotranspiration $(\mathrm{mm} /$ day $)$

$\mathrm{ET}_{\mathrm{o}}=$ reference evapotranspiration $(\mathrm{mm} /$ day $)$; and

$\mathrm{K}_{\mathrm{c}}=$ crop coefficient

\section{RESULTS AND DISCUSSION}

Data in Table 4 and Fig (1) show that the applied treatments, in general, significantly increased the mean value of available- $K$ at the different time growth compared to control. The highest effect in increasing available $\mathrm{K}$ was generally obtained from rice straw compost + banana residues compost, rice straw compost + vegetables residues compost and rice straw compost + bio fertilizer treatments. Meanwhile, rice straw compost alone treatment caused the lowest effect. To obtain the maximum potassium availability, the first derivative of the time growth function equations is set equal zero and solving it. Results presented in Table (4) show the maximum potassium in loamy soil reached to $2.96,3.58,3.38$, 3.2 and $3.35 \mathrm{meq} / \mathrm{l}$ at 475, 508, 457,494 and 350 hour, respectively. The corresponding figures for sandy soil achieved 475, 375, 550, 575 and 425 hour producing the maximum potassium of $0.41,0.58,1.71,1.08$ and $1.06 \mathrm{meq} / \mathrm{l}$ at different time growth under the rice straw compost 
treatments. Based on the course of $\mathrm{K}$ accumulation during the growth season, three main characteristics of $\mathrm{K}$ uptake by a particular crop can be determined. They are as follows: (i) maximum K, (ii) the absolute rate of $\mathrm{K}$ accumulation, and (iii) the relative rate of $\mathrm{K}$ accumulation, which is useful in determining the earliest to a particular nutrient supply.
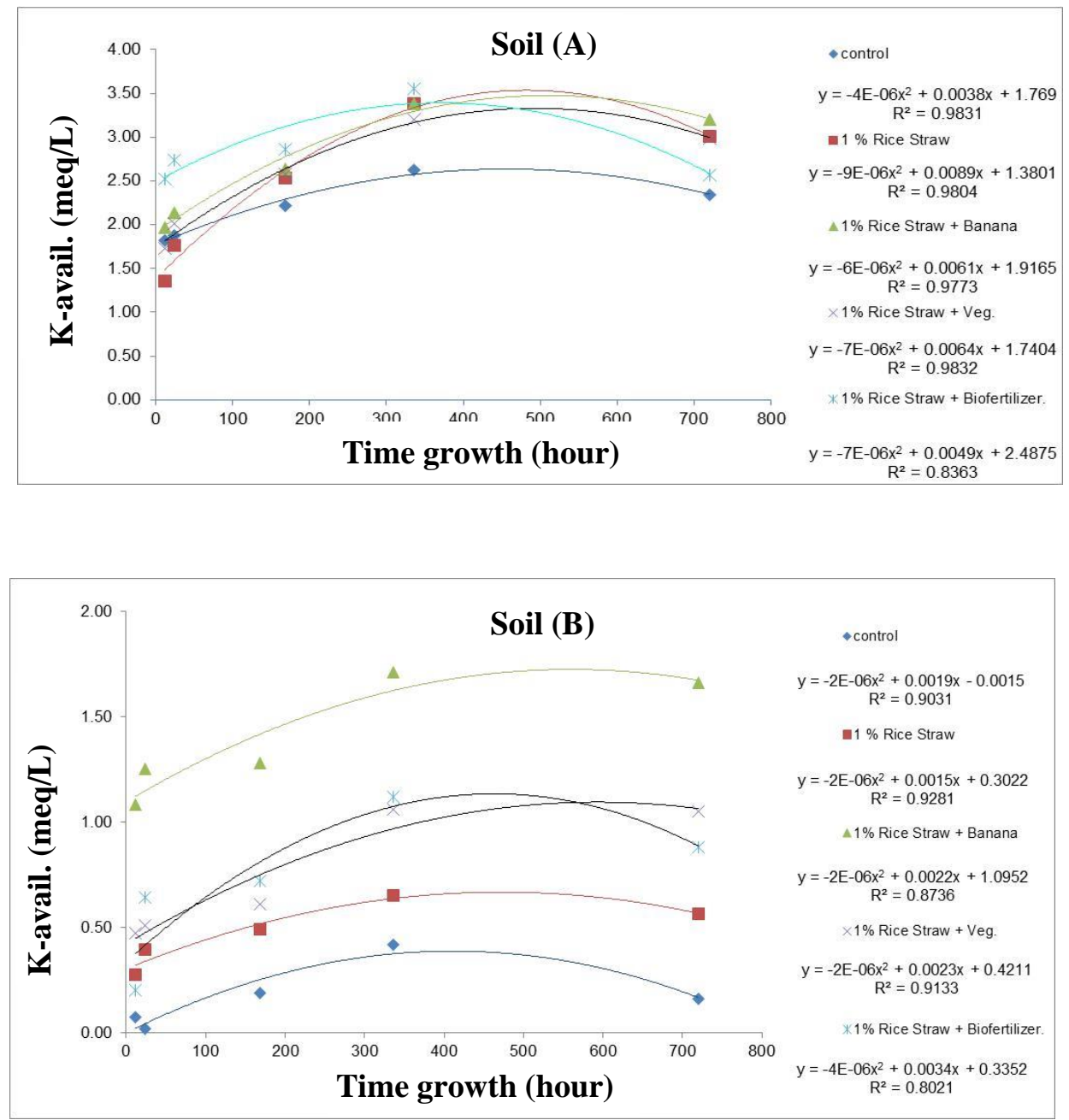

Fig ( 1 ): Relationship between K- availability and time growth in soil study

In the present case, the RRAK reached a maximum around the $7^{\text {th }}$ week after plant emergence (Malnou et al., 2006). 
Table 4: Maximum potassium availability and time applied for barley crop under different treatments

\begin{tabular}{|c|c|c|c|}
\hline Treatments & $\begin{array}{c}\text { Max. potassium } \\
\text { (meq/l) }\end{array}$ & $\begin{array}{c}\text { Time growth } \\
\text { (hour) }\end{array}$ & $\begin{array}{c}\text { Time as the ratio } \\
\text { of potassium } \\
\text { (\%) }\end{array}$ \\
\hline i) loamy soil \\
\hline Control & 2.96 & 475 & 70 \\
RSC & 3.2 & 494 & 68 \\
RSC+BRC & 3.58 & 508 & 66 \\
RSC+VRC & 3.38 & 457 & 73 \\
RSC+Bio & 3.35 & 350 & 96 \\
\hline ii) sandy soil & \multicolumn{3}{|}{} \\
\hline Control & 0.41 & 475 & 70 \\
RSC & 0.58 & 375 & 89 \\
RSC+BRC & 1.71 & 550 & 61 \\
RSC+VRC & 1.08 & 575 & 58 \\
RSC+Bio & 1.06 & 425 & 79 \\
\hline
\end{tabular}

\section{Applied water}

Data presented in Table (5) show the mean values of applied water amount under drought condition (100, 80, 60\% from $\left.\mathrm{ET}_{\mathrm{c}}\right)$.

Table 5: Water amount of evapotranspiration crop under barley crop at different stages of growth

\begin{tabular}{|c|c|c|c|c|c|c|c|c|c|c|}
\hline \multirow{2}{*}{$\begin{array}{l}\text { Growth } \\
\text { stage }\end{array}$} & \multirow{2}{*}{ Month } & \multirow{2}{*}{$\begin{array}{l}\text { Crop } \\
\text { coeff. }\end{array}$} & \multirow{2}{*}{$\begin{array}{c}\mathbf{E T}_{\mathbf{0}} \\
\mathbf{m m} / \mathbf{d a y}\end{array}$} & \multirow{2}{*}{$\begin{array}{l}\text { Length } \\
\text { (days) }\end{array}$} & \multicolumn{2}{|c|}{$\begin{array}{c}100 \% \\
\text { ET }_{\mathbf{c}}\end{array}$} & \multicolumn{2}{|c|}{$\begin{array}{c}80 \% \\
\text { ET }_{\mathbf{c}}\end{array}$} & \multicolumn{2}{|c|}{$\begin{array}{c}60 \% \\
E^{2} T_{c}\end{array}$} \\
\hline & & & & & \begin{tabular}{|c|}
$\mathbf{m m} /$ \\
day
\end{tabular} & $\begin{array}{l}\mathrm{mm} / \\
\text { stage }\end{array}$ & $\begin{array}{c}\mathrm{mm} / \\
\text { day }\end{array}$ & $\begin{array}{l}\mathrm{mm} / \\
\text { stage }\end{array}$ & $\begin{array}{c}\mathrm{mm} / \\
\text { day }\end{array}$ & $\begin{array}{l}\text { mm/ } \\
\text { stage }\end{array}$ \\
\hline Initial & Nov. & 0.3 & 1.97 & 15 & 0.59 & 8.9 & 0.47 & 7.0 & 0.35 & 5.31 \\
\hline Develop. & Dec. & 0.7 & 1.25 & 15 & 0.88 & 13.1 & 0.7 & 10.6 & 0.53 & 7.92 \\
\hline Sur & & & & & & 22 & & 17.6 & & 13.2 \\
\hline
\end{tabular}

Data presented in Tables (5 and 6) show the effect of the water consumption values $(100,80$ and $60 \%)$ on barley dry matter and potassium content, which has been added to RSC $1 \%$ or mixed with BRC, VRC and biofertilizer as a source of nutrient plant potassium. There is a significant and clear effect by using RSC+BRC on water 
consumption under 100 and $60 \%$ referring to the effect of potassium nutrition. The physiological roles of $\mathrm{K}$ in plants have been extensively described in recent reviews (Marschner, 2012). Shao et al. (2009) characterize the physiological functions of water at three levels: (i) cellular (as a component and medium for biochemical reactions), (ii) tissue (as a link to adjacent cells) and (iii) whole plant (as a means of mineral nutrient and hormone transport. In agronomy, a fourth operational level of water's effect on a crop plant has been developed that summarizes all basic processes at the canopy level. This index is known as the water-use-efficiency (WUE) index, and in a broad sense it describes the quantity of biomass produced by a particular crop plant in relation to the volume of water that is evaporated and transpired during its life cycle.

Table (6) Effect of water requirements on dry matter and $K$ content in different soil

\begin{tabular}{|c|c|c|c|c|c|c|c|c|c|}
\hline \multicolumn{10}{|c|}{ Loamy soil } \\
\hline \multirow[b]{2}{*}{ Treatment } & \multicolumn{3}{|c|}{$100 \%$ Ir. Req } & \multicolumn{3}{|c|}{$80 \%$ Ir. Req } & \multicolumn{3}{|c|}{$60 \%$ Ir. Req } \\
\hline & $\begin{array}{c}\text { dry } \\
\text { matter }\end{array}$ & $\begin{array}{c}\text { K- } \\
\text { cont. }\end{array}$ & & $\begin{array}{c}\text { dry } \\
\text { matter }\end{array}$ & $\begin{array}{c}\text { K- } \\
\text { cont. }\end{array}$ & & $\begin{array}{c}\text { dry } \\
\text { matter }\end{array}$ & $\begin{array}{c}\text { K- } \\
\text { cont. }\end{array}$ & \\
\hline Control & 12.42 & 0.585 & $\mathrm{e}$ & 21.84 & 0.771 & $\mathrm{f}$ & 12.66 & 0.599 & $\mathrm{~d}$ \\
\hline $1 \% \mathrm{RSC}$ & 14.83 & 1.522 & d & 23.23 & 1.779 & $\mathrm{a}$ & 12.95 & 0.825 & $\mathrm{c}$ \\
\hline $1 \% \mathrm{RSC}+\mathrm{BRC}$ & 33.46 & 1.971 & $\mathrm{a}$ & 24.75 & 1.108 & de & 29.63 & 1.89 & $\mathrm{a}$ \\
\hline $1 \% \mathrm{RSC}+\mathrm{VRC}$ & 14.32 & 1.696 & $\mathrm{bc}$ & 17.55 & 1.1 & $\mathrm{e}$ & 15.74 & 1.016 & b \\
\hline 1\% RSC+Bio & 14.58 & 1.681 & $\mathrm{ab}$ & 29.07 & 1.341 & $\mathrm{bc}$ & 14.52 & 1.246 & $\mathrm{a}$ \\
\hline Average & 17.922 & 1.491 & A & 23.288 & 1.220 & B & 17.100 & 1.115 & A \\
\hline \multicolumn{10}{|c|}{ Sandy soil } \\
\hline Control & 5.59 & 1.142 & $\bar{d}$ & 6.20 & 1.142 & $\mathrm{~d}$ & 9.10 & 0.195 & $\bar{d}$ \\
\hline $1 \% \mathrm{RSC}$ & 27.40 & 1.501 & $\mathrm{~b}$ & 26.33 & 1.501 & $\mathrm{~b}$ & 16.17 & 0.667 & $\mathrm{c}$ \\
\hline $1 \% \mathrm{RSC}+\mathrm{BRC}$ & 19.46 & 1.616 & $a b$ & 7.61 & 1.616 & $\mathrm{ab}$ & 29.95 & 1.166 & $\mathrm{a}$ \\
\hline $1 \% \mathrm{RSC}+\mathrm{VRC}$ & 20.50 & 1.276 & $\mathrm{~cd}$ & 27.27 & 1.646 & $\mathrm{ab}$ & 22.64 & 1.105 & $\mathrm{a}$ \\
\hline 1\% RSC+Bio & 12.36 & 1.646 & $a b$ & 20.66 & 1.704 & $\mathrm{a}$ & 23.54 & 1.13 & $\mathrm{a}$ \\
\hline Average & 17.062 & 1.436 & A & 17.614 & 1.522 & $\mathbf{A}$ & 20.280 & 0.853 & B \\
\hline
\end{tabular}

\section{REFERENCES}

Agricultural Climatologic Profiles (2013). Central Laboratory for Agricultural Climate, Agriculture Research Center, Ministry of Agriculture and Land Reclamation. 
Allen, R.G.; L.S. Pereira; D. Raes and Smith, M. (1998). Crop evapotranspiration, guidelines for computing crop water requirements, Irrigation and Drainage. FAO, Rome, Paper No. 56 Part A, pp. 15-79.

Amtmann, A. and Armengaud, P. (2009). Effects of N, P, K and S on metabolism: New knowledge gained from multi-level analysis. Curr. Opin. Plant Biol., 12, 275-283.

Doorenbos, J.; Pruitt, W.O.; Aboukhaled, A.; Damagnez, J.; Dastane, N.G.; Van Den Berg, C.; Rijtema, P. E.; Ashford, O. M. and Frere, M. (1977). Guidelines for predicting crop water requirements, Irrigation and Drainage FAO, Rome. Paper No. 24, pp. 35-95.

Calderini, D.F. and Slafer, G.A. (1999). Has yield stability changed with genetic improvement of wheat yield? Euphytica 107, 51-59.

Fanning, D. S. and Keramidas, V. Z. (1977) Micas. In: "Minerals in Soil Environments", J. B. Dixon and S. B. Weed (Ed.), SSSA, Madison, WI.

FAO STAT (2012). www.faostat.fao.org (accessed 2012-12-15). Jackson, M.L. (1973). Soil chemical analysis. Prentice-Hall of India Private Limited, New Delhi.

http://www.wunderground.com/history/airport/HECA/2013/6/30/M onthlyHistory.html\#calendar, 2013).

Grzebisz, W., and J. Diatta, (2012). Constraints and solutions to maintain soil productivity: a case study from central Europe. In: J. Whalen (Ed.), Soil fertility improvement and integrated nutrient Management-a global perspective. In Tech Europe, Rijeka, Croatia, pp159-182. 
Grzebisz, W.; Pepliñski, K.; Szczepaniak, W.; Barłóg, P. and Cyna, K. (2013). Impact of nitrogen concentration in sugar beet plant parts throughout the growing season on dry matter accumulation patterns. J. Elementology 17, 389-408.

Hawkesford, M.; Horst, W.; Kichey, T.; Lambers, H.; Schjoerring, J.; Skrumsager Møller, I. and White, P. (2012). Functions of micronutrients, in: Marschner, P. (ed.): Marschner's Mineral Nutrition of Higher Plants. Elsevier Ltd., Amsterdam, The Netherlands, pp.135-190.

Malnou, C.S.; Jaggard, K.W. and Sparkes, D.L. (2006). A canopy approach to nitrogen fertilizer recommendation for the sugar beet crop. Europ. J. Agron. 25, 254-263.

Marschner, P. (2012): Marschner's Mineral nutrition of higher plants. Elsevier Ltd., Amsterdam, p. 651.

Rady, M.M. and Maybelle S. Gaballah (2012). Improving barley yield grown under water stress conditions, Research Journal of Recent Sciences,1,(6):1-6.

Page, A.L.; Miller, R.H. and Keeny, D.R. (1982). Methods of Soil Analysis Part II. Chemical and Microbiological Properties, $2^{\text {nd }}$ ed., Amer. Soc. Agron., Monograph No.9, Madison,Wisconsin, U.SA.

Shao, H..B.; Chu, L.Y.; Jaleel, C.A.; Manivannan, P.; Panneerselvam, R. and Shao, M.A. (2009): Understanding water deficit stress-induced changes in the basic metabolism of higher plants - biotechnologically and sustainable improving agriculture and the ecoenvironment in arid regions of the globe. Crit. Rev. Biotech. 29, 131-151.

Snedecor, G.W. and W.G. Cochran. (1982). Statistical. Methods 6th Edn. Iowa State University Press, Ames. Iowa. 
Wood, S.; Sebastian, K. and Scherr, S.J. (2000). Soil resource condition, in: Pilot analysis of global ecosystems: Agroecosystems. World Resource Institute, Washington, USA, pp. 45-54.

Zhang, X., Chen, S., Sun, H., Wang, Y., Shao, L. (2009): Root size, distribution and soil water depletion as affected by cultivars and environmental factors. Field Crops Res. 114, 75-83.

\section{الملخص العربح \\ تاثير سماد قش الارز كمصدر للبوتاسيوم على المادة الجافة لنبات الثعير تحت ظروف الجفاف}

\section{منال مبارك ا}

الهدف الرئيسي من هذا البحث دراسة تأثير سماد قش الأرز كمدر للبوتاسيوم على أساس

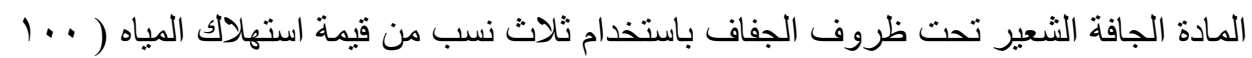

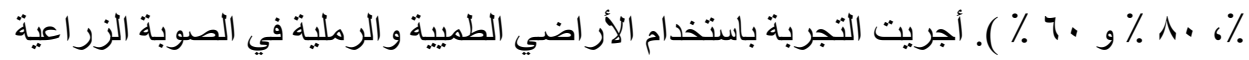

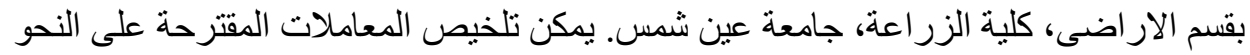

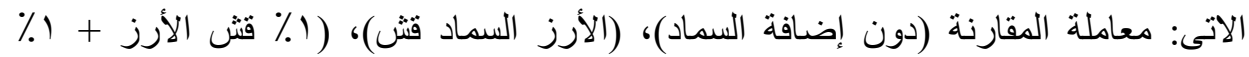

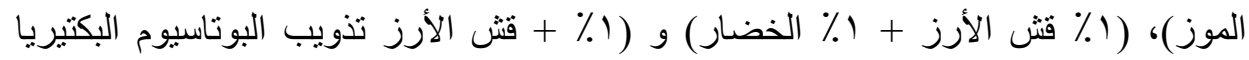

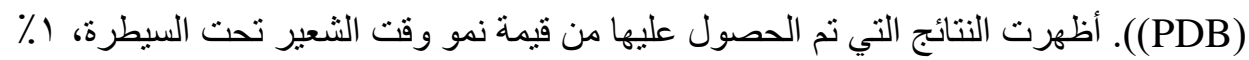

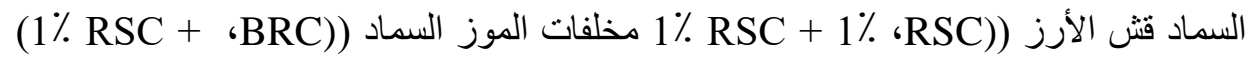

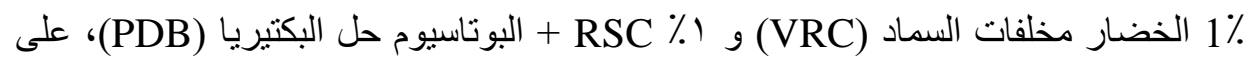

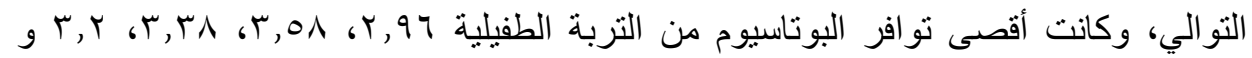

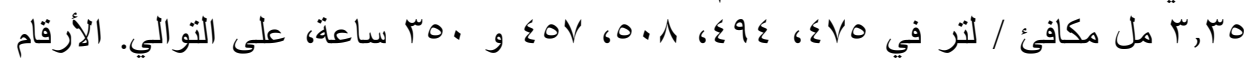

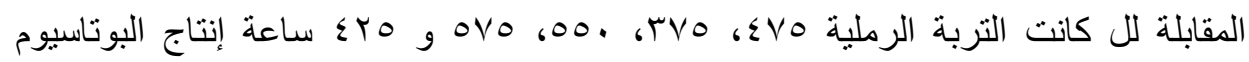

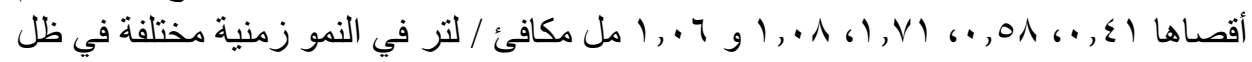

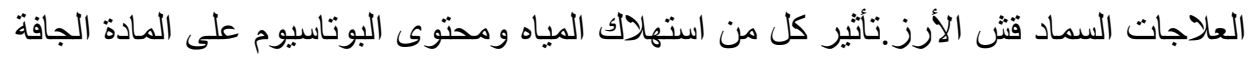

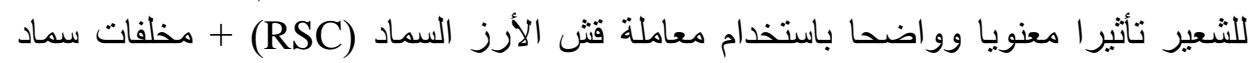

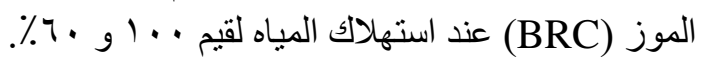

ا ـ قسم الاراضى ـ كلية الزراعةـ جامعة عين شمس - شبرا الخيمةـ القاهرة.

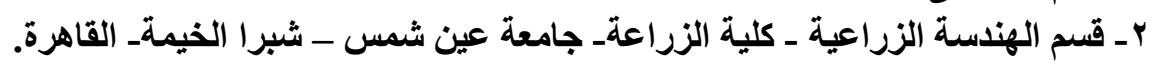

